\title{
The influence of micro economic factors on the default risk of leasing industry
}

\author{
${\text { Gholamreza Farsad Amanollahi }{ }^{a^{*}} \text { and Joriah Binti Muhammad }}^{\mathrm{b}}$
}

${ }^{a}$ Faculty Member, Department of Management and Accounting, Central Branch, Islamic Azad University, Tehran, Iran ${ }^{b}$ School of Management, University Science of Malaysia11800 USM, Penang, Malaysia

\begin{tabular}{l}
\hline C H R O N I C L E \\
\hline Article history: \\
Received June 5, 2015 \\
Received in revised format \\
August 162015 \\
Accepted November 82015 \\
Available online \\
November 182015 \\
\hline Keywords: \\
Leasing \\
Default risk \\
Internal and external factors
\end{tabular}

\section{A B S T R A C T}

\begin{abstract}
The aim of this study is to establish a framework for measuring and managing credit risk for fifteen leasing companies in Iran. An analysis on the influence of internal factors on credit performance will then be performed. This will enable a leasing industry to progress towards its goals and objectives in the most direct and effective way. Credit risk consists of probability of non-return. This may be in the form of bankruptcy or a decrease in financial and credit situation of the lessee. We can assume a correlated market and credit risk. The variables are extracted from the Central Bank of Kanoon Leasing Association in Iran. Numerical analysis reveals that lessee credit risk can have a substantial impact on a lease term structure.
\end{abstract}

Internal and external factors

\section{Introduction}

A lease is a written agreement between the owner of the equipment, called the lessor, and a person who utilizes the equipment for a definite time at a given price. This may be referred to as periodic rent (Deelen et al., 2003). This type of contract consists of different parts: buyers or lessee, contract duration, amount and due date of rental payments, configurations of the equipment, its current condition, and the date for the nullification of the contract (Boobyer \& Christopher, 2003). In terms of execution, leasing consists of several specialized steps based on the renting style in which the contract is signed between two or more people. The lessee can be an individual or legal representative, who utilizes the benefits of the commodity or the commodity itself. This can be either a property, tenant, or durable consumer (Hildreth, 1993). The style may include a collection of economic transactions. Buying or renting can produce a contract of ownership. In other words, the contract is signed between a leasing company, which is the owner or lessor, and the user of the rented facility (Stewart, 1994).

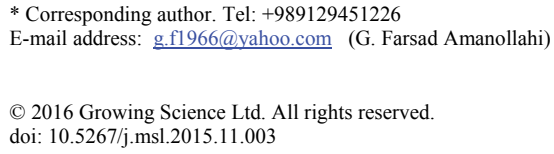


A vital and important subject in the allocation of credit to the lessee is the evaluation of credit risk. When companies involve decision making they must have high regard to investment to the firms' bonds in the evaluation of credit risk of lessee and bond issuers. The possibility of the anticipated rate of return in investment projects is called risk (Deelen et al., 2003). Business cycles, inflation, political situations and many other factors play a part in the trust or lack of trust in the future. An important issue in allocating a financial institution's credit such as leasing institutions and banks is assessing customers' credit risk. Assessing the possibility of non-recovery of the anticipated return rate in valuating capitalization is called risk (Aven, 2010; Aven \& Renn, 2009), in other words, a lack of trust in investment future earnings. Business cycles, inflation, political situations and many other factors influence on lack of trust. A highly significant investment principle in all fields is that risk of investment, which should be in balance with the return of investment. Therefore, identifying skills of credit analysis in financial institutions is especially important (Bhattacharya, 2010).

When a customer applies for credit facilities or a lease, the institution ensues to give services after viewing customer's documents. Leasing tries to give facilities to customers who are fully capable of repaying the principal and interest in an agreed specified time (Krause, 2006). Modeling portfolio credit risk tends to be a relevant issue in credit risk analysis. One issue may be a modeling portfolio credit risk to aid in the development of an appropriate model. This helps quantify the interaction effects of the high risk credit entities within a portfolio. According to Moodys' Binomial Expansion Technique (BET), a model has been extensively used in finance and insurance industries. The BET model is adapted to believe that the any defaults in a bond portfolio are binomially distributed. This is with the intention of handling the dependence of defaults that the notion of diversify score was introduced in the BET model. This score groups the dependent leases jointly and shrinks the number of dependent existing leases. In every time step as the number of autonomous credit risk entities are identified, the BET model may be applied. It gives an extension to the BET model dependence of the default correlation in such a way that it defaults in a lease portfolio (Lee, 2006).

Default risk is also classified as credit risk. Schmit (2004) performed a survey reported that there was a direct relationship between default risk and the term of rental contracts. In other words, by an increase in contract terms, default risk also increases. It has also been proven that there is a reverse relationship between default risk and contract amount where others have revealed that the default risk of different economy parts were considerably different. Kisgen (2006) provided evidence that ratings effect of capital structure decisions when firms are near a credit default upgrade or downgrade. Faulkender and Petersen (2006) found that credit default is associated with better access to public debt markets and higher leverage. Previous research explains the analysis of various independent variables and found specific results in the relationships of the independent and dependent variables.

\section{Conceptual framework and hypotheses development}

Based on the literature review the structural analysis will be presented in line with Lee (2009). The usefulness of Lee's framework in presenting the evolution of the leasing industry in Iran is detailed as follows. Altman (1989), Shanmugam and Das (2004), Tang (2008) argued that the internal factors are not the only factors influencing on default risks and there are some other external factors that need to be considered. The internal approach only focuses on the internal characteristics in management's control while the external approach concentrates on the sensitivity of default risk to the changes in the economic environment.

\subsection{The Research Hypotheses}

Based on the proposed conceptual framework, several hypotheses will be developed in order to investigate the relationships between internal and default risk. 
Default: is an exposure to loss for the lack of payment by the borrower of an obligation on a loan agreement. Any credit obligation is considered default if more than 90 days pass the due date (Basel Committee on Banking Supervision, 2001). Few studies surround the idea of default risk and probability default (PD) along with the loss given default (LGD). Moreover, studies have used the number of deferred payments as a default measurement (e.g. Altman, 1989; Schallheim et al., 1987; McConnell \& Schallheim, 1990; Grenadier, 1996; Siu et al., 2005; Rahmani, 2011). They aggregated these studies into the default risk dimensions of lease yield, recovery rate, interest rate, gross domestic product and foreign exchange rate. This is one of the oldest investigation review procedures known to be used by scholars. Financial instruments are often used to perform time-series analysis, crosssectional analysis, panel-data analysis, profit analysis, trend analysis, correlation analysis, and regression analysis. The default data are obtained from the Central Bank and Kanoon Leasing Association in Iran. There is a relationship between default and internal variables:

Upfront prepayment (UPPR): There are cases where a borrower pays for a loan in advance as an upfront payment at the start of the subscription (Schmit, 2004; Grenadier, 1996). Upfront prepayment is widely implemented to measure the overall default and risk of a leasing and financial institute. Schallheim and McConnell (1990) and Madura (2003) used upfront prepayment as a default to measure credit risk. In light of the above rationale, the relationship between upfront prepayment and default is hypothesized as follows:

Hypothesis 1: Upfront prepayment is a negative relationship with default on the leasing industry.

Credit insurance contract (CRINCO): It is a legal agreement in which conditions of the coverage, policy terms, and costs are indicated by the insurance company. Consideration of the offer and the acceptance, indemnification, legal capacity and purpose are standardized features of an insurance contract (Porter et al., 2007). Credit risk is typically shared among the provider and user of lease agreement, which may be a public or private firm (Woo et al., 2004; Feldstein \& Fabozzi, 2011). Credit insurance is a way to insure repayment of a lease even if the lessee loses his/her job, becomes disabled, or is deceased. All kinds of loans including home mortgage borrowing, car loans, credit card debt as well as loans from finance companies can be purchased by consumer credit insurance companies. Consumer credit insurance benefits are available for both the consumer and the financing company who purchase credit insurance for extending the credit to the consumers (Nelson \& Loehman, 1987). Schallheim and McConnell (1985) and Elsas and Krahnen (2000) were among researchers initiated the use of insurance contracts as a measurement for default risk and credit. Based on the rationale, the relationship between credit insurance contracts and defaults poses the following hypothesis:

Hypothesis 2: Credit insurance contracts are positively related to defaults in the leasing industry.

Security deposits (SEDE): 'Security deposits' have different meanings in different parts of the world. Security deposits guarantee nonpayment of installments and other damages (Stickney et al., 2009). Elsas and Krahnen (2000), Tong (1977) and Schmit and Stuyck (2002) reported that the security deposits of bank loans had positive outcomes such as decreasing credit risk as well as increasing the access of borrowers to debt financing. Based on this rationale, the relationship between security deposits and defaults is hypothesized as follows:

Hypothesis 3: Security deposits have positive relationships with defaults on the leasing industry.

Time and period contract (TPCO): the leasing period for a contract is considered a reasonable time that begins with agreements of both parties. The contract duration is a reverse relationship with the rate (Schmit, 2004; Grenadier, 1996; Miri, 2008). Researchers have demonstrated the default risk of banking and time, which influence on equity returns and default risk. In light of the above reasoning, the relationship between time, period of contracts and defaults are hypothesized as follows:

Hypothesis 4: the time period of a contract has an overall positive relationship with a default in the leasing industry. 
Collateral and guarantees (COGU): collateral generally refers to a financial institution's taking-back of an object that was either used as repossession or rented leased in transactions. Repossession is a "self-help" type of action in which the owner of the property takes the aforementioned property back from the sectors, thus, having the right of possession without invoking court proceedings. Schmit (2004) and Pozzolo (2004) showed negative relationships between the interest rate on bank loans and the presence of collaterals and guarantees. This study examines these factors in accordance to the following hypothesis:

Hypothesis 5: Collateral and guarantee show a negative relationship with default in the leasing industry.

\subsection{Estimation Model}

Based on the above discussion, Eq. (1) illustrates the estimation model that is used in the present study:

$$
Y i t=\beta_{0}+\beta_{1} X_{i t}+\beta_{2} X_{j t}+\ldots+X_{m t}+e_{i t}
$$

where $Y_{i t}$ is the credit risk for company $i$ at period $t ; X_{i t}$ represents the antenatal factors for company $i$ at period $t ; X_{j t}$ is the external factors and finally $e_{i t}$ is an error term. The internal factors include (UPPR, CRCO, SEDE, TPCO, and COGU)

Credit risk $=f(U P P R, C R C O, S E D E, T P C O, C O G U)$

In addition, Table 1 mentions the variables that used in this paper.

\section{Table 1}

Explanatory variables

\begin{tabular}{lll}
\hline \multicolumn{2}{c}{ Internal Factors } & Expected sign to default \\
\hline $\mathrm{X}_{1}$ & Up front prepayment (UPPR) & Negative \\
$\mathrm{X}_{2}$ & Credit insurance contract (CRCO) & Negative \\
$\mathrm{X}_{3}$ & Security deposits (SEDE) & Negative \\
$\mathrm{X}_{4}$ & Time and period contract (TPCO) & Positive \\
$\mathrm{X}_{5}$ & Collateral and guarantees (COGU) & Negative \\
\hline
\end{tabular}

\subsection{Data Sources and Data Model}

The researchers have used official records and public documents. These have been accessed by the extensive use of archives of the central Bank of Iran, Kanoon of Leasing in Iran and the Iran Stock Exchange. Six years of collected data are from 2005 to 2010. From the total of all leasing activities, approximately $90 \%$ belongs to 15 leasing companies and $10 \%$ to other companies with leasing activities (Central Bank and Kanoon leasing Association of Iran, 2011). In reference to using the panel data model with its data limitation across companies over time ( 15 companies and 7 years), currently, it was not feasible to do cross-section or time-series study applications, therefore, the panel data analysis was applied.

\subsection{Estimation of Default Risk}

The focus was mainly on the determinants of leasing companies using internal (microeconomic) and external (microeconomics) variables. This would include the various regression analysis carried out on 15 leasing companies in Iran from 2005 to 2010. In additional, it was imperative to assume that an underlying analysis was examined before the estimation model was tested. The assumptions to be addressed for the variables were the linearity and normality test of equal variance (Homoscedasticity). In additional, the correlation analysis was measured.

\subsection{Introductory Statistics}

Brief statistics for the variables utilized in this research is shown in Table 2 for the default and nondefault groups. Table 2 demonstrated that the mean of UPPR for defaulted installment was negative ($2.2)$, though positive for non-defaulted groups (0.22). In addition, the means of the variables CRCO, TPCO, and COGU had a positive value while the SEDE had a negative mean in the defaulted group 
thought it was evaluated with a positive mean in the non-defaulted group. Table 3 explains the correlation matrix of the variables in the default and non-default groups. The low inter-correlations between the explanatory variables (among defaulted and non- defaulted) utilized in the regressions have indicated no cause of erroneous results. When testing for heteroscedasticity, a Lagrange Multiplier test by Breusch-Pagan (Breusch \& Pagan, 1979) was developed. The results demonstrated that our models do not tolerate the use of heteroscedasticity for this particular need.

Table 2

Summary Statistics for Default and Non-Default

\begin{tabular}{|c|c|c|c|c|c|c|c|c|c|c|c|c|}
\hline & \multicolumn{6}{|c|}{ Default } & \multicolumn{6}{|c|}{ Non-Default } \\
\hline & Mean & Variance & Median & Max & Min & STDV & Mean & Variance & Median & Max & Min & STDV \\
\hline UPPR & -2.2 & 40.54 & -0.16 & 0.04 & -30.65 & 6.58 & 0.22 & 0.32 & 0.13 & 1.73 & -1.23 & 0.56 \\
\hline CRCO & 0.97 & 6.49 & 0.65 & 7.04 & -5.74 & 2.43 & 0.52 & 0.22 & 0.41 & 1.86 & 0.025 & 0.47 \\
\hline SEDE & -0.27 & 0.36 & -0.126 & 1.05 & -1.2 & 0.41 & 0.02 & 0.026 & 0.06 & 0.35 & -0.27 & 0.127 \\
\hline ТPCO & 0.18 & 0.44 & -0.146 & 0.93 & -2.17 & 0.58 & 0.21 & 0.18 & 0.17 & 0.4 & 0.37 & 0.28 \\
\hline COGU & 0.38 & 0.14 & 0.26 & 0 & 1.29 & 0.56 & 0.57 & 0.231 & 0.48 & 1.94 & 0 & 0.48 \\
\hline
\end{tabular}

Table 3

Correlation Matrix of Variables

\begin{tabular}{|c|c|c|c|c|c|c|c|c|c|c|c|}
\hline & & \multicolumn{2}{|c|}{ UPPR } & \multicolumn{2}{|c|}{$\mathrm{CRCO}$} & \multicolumn{2}{|c|}{ SEDE } & \multicolumn{2}{|c|}{ TPCO } & \multicolumn{2}{|c|}{$\mathrm{COGU}$} \\
\hline & & DF & ND & DF & ND & DF & ND & DF & ND & DF & ND \\
\hline \multirow[t]{2}{*}{ UPPR } & DF & 1 & & & & & & & & & \\
\hline & ND & 0.318 & 1 & & & & & & & & \\
\hline \multirow[t]{2}{*}{$\mathrm{CRCO}$} & DF & 0.37 & 0.37 & 1 & & & & & & & \\
\hline & ND & 0.212 & 0.28 & 0.11 & 1 & & & & & & \\
\hline \multirow[t]{2}{*}{$\begin{array}{l}\text { SEDE } \\
\end{array}$} & $\mathrm{DF}$ & -0.202 & -0.29 & -0.502 & -0.06 & 1 & & & & & \\
\hline & ND & 0.3 & 0 & 0.142 & 0.204 & 0.03 & 1 & & & & \\
\hline \multirow[t]{2}{*}{ TPCO } & DF & 0.394 & 0.12 & -0.391 & 0.057 & 0.38 & 0.233 & 1 & & & \\
\hline & ND & 0.17 & -0.11 & 0.118 & 0.187 & 0.12 & 0.212 & 0.08 & 1 & & \\
\hline \multirow[t]{2}{*}{$\mathrm{COGU}$} & DF & 0.47 & 0.12 & 0.507 & 0.076 & -0.22 & 0.15 & 0.21 & 0.262 & 1 & \\
\hline & ND & 0.186 & 0.45 & 0.225 & 0.147 & -0.22 & -0.28 & -0.11 & -0.081 & 0.081 & 1 \\
\hline
\end{tabular}

\subsection{Parameter Estimation and Hypothesis Test}

Table 4 summarizes the results of the Logit models analyses using a matched sample. Analogue to the linear regression, the analysis of Logit model, gives the approximated coefficient of the variables and the ratios to examine the assumption that each coefficient. Predicting the PD. Is a significant Cause of Hypothesis 1, the variable representing the leasing companies' upfront prepayment is expected to affect the corporate failure negatively. Table 4 shows the results of the sample. The coefficient of the UPPR, as suspected, is negatively and significantly related to the possibility of default. The negative sign points out that leasing companies with a high UPPR ratio have a decreased probability of default. Leasing companies with a high UPPR have a low debt ratio and a lower likelihood of default, as corporate cash flow displays the initial sources of funds. The findings of prior research including Zeitun (2009), have shown a negative relationship between a UPPR and the probability of default.

Hypothesis 2 predicts that leasing companies with a high CRCO tend to have a lower probability of default. From the regression results in Table 1, as expected by the cash flow theory, the coefficient of CRCO is significant at the $5 \%$ level of significance and show a negative value. A negative value is a significant sign which guides to the acceptance of the hypothesis where leasing companies with high contract credit insurance have a low probability of default.

Regarding hypothesis 3, the coefficient of SEDE is found to be negative with a significant level of $1 \%$. A negative sign indicates that leasing companies with high Security deposits have a lower probability of default. This is a uniform result with earlier works of Altman (1989). In addition, the coefficients for the SEDE are negative and significance as a minimum of $10 \%$ and $1 \%$ levels, respectively. This is also consistent with the cash flow theory. Since a leasing company is able to create cash flow and cover 
its obligation then, in turn, will decrease its probability of default. This further leads to an approval of the hypothesis. Leasing companies with low cash flow ratios have a higher probability of default. Hypothesis 4 reveals the coefficient of TPCO as negatively and significantly related to the possibility of default. The negative sign has pointed out that leasing companies with a high TPCO ratio have a decreased probability of default. Leasing companies with a high TPCO have a low debt ratio and a lower likelihood of default, as corporate cash flow displays the initial sources of funds. The finding of prior research including Schmit (2004) who reported a negative relationship between TPCO and the probability of default.

Hypothesis 5 predicts that leasing companies with a high COGU tend to have a lower probability of default. As seen from the regression results, it was expected through cash flow theory that the coefficient of COGU would be significant at the $11 \%$ level of significance and negativity. The positive and the significance sign guide align to an acceptance of the hypothesis whereby leasing companies with a high collateral and guarantee of contract decrease the default probability.

\section{Table 4}

Estimated Coefficients for the Participation Model

\begin{tabular}{lcc}
\hline Variables & Expected Sign & Coefficient Estimates \\
\hline Constant & & $-41.32(-2.34)$ \\
UPPR & - & $2.282(-1.897)$ \\
CRCO & - & $11.602(-2.092)$ \\
SEDE & - & $-6.452(-2.55)$ \\
TPCO & - & $-12.278(-1.6874)$ \\
COGU & - & $-7.078(-2.58)$ \\
\hline Percent of success & & 0.914 \\
Log-likelihood & & 13.344 \\
Likelihood Ratio statistic & & $(55.084)$ \\
\hline (LR) McFadden $R 2$ & & 0.66 \\
\hline
\end{tabular}

Table 4 shows the regression results where the coefficients of UPPR, SEDE, CRCO, and COGU are negative and significant in predicting the probability of default. TPCO was found to have a significant and positive impact on leasing companies' probability of default. The empirical results for the panel samples are demonstrated in Table 5.

Table 5

Estimated Coefficients for the Participation Model two and three years before default

\begin{tabular}{|c|c|c|}
\hline Variables & Two years before default & Three years before default \\
\hline \multirow{2}{*}{ UPPR } & -1.1541 & $(-1.197)$ \\
\hline & -2.7285 & $(-1.2346)$ \\
\hline \multirow{2}{*}{ TPCO } & 2.5981 & $(0.80343)$ \\
\hline & 3.7801 & $(1.2579)$ \\
\hline \multirow{2}{*}{ SEDE } & -4.2009 & $(-2.2421)^{* *}$ \\
\hline & -2.0641 & $(-1.479)$ \\
\hline \multirow{2}{*}{$\mathrm{CRCO}$} & -3.0894 & $(-0.76014)$ \\
\hline & 3.9954 & $(0.8127)$ \\
\hline \multirow{2}{*}{ COGU } & -4.2020 & $2.2018)^{* *}$ \\
\hline & -4.3282 & $(-2.758) * * *$ \\
\hline \multirow{2}{*}{ Constant } & 25.554 & $(2.1164)^{* *}$ \\
\hline & 25.962 & $(2.708) * * *$ \\
\hline No.of Observations & 1557 & P-value $(0)^{* * *}$ \\
\hline Wald test & 5584.40 & Rhop (1) $0.4635^{* *}$ \\
\hline Log likelihood & -164.69 & \\
\hline Adjusted R-square & 0.20 & \\
\hline
\end{tabular}


It is demonstrated that the probability of default decreases for a firm with possible increases in higher upfront prepayments (UPPR), higher Security deposits (SEDE), credit insurance contracts (CRCO). To investigate the effects of the selected variables on a leasing companies' probability of default, a marginal result after the logistic estimation is formulated. The COGU has the highest positive marginal effect on a leasing companies' probability of default followed by TPCO, with $3.799 \%$ and $0.873 \%$ respectively. The marginal effects show that COGU and TPCO have the greatest effect in formative and increasing the probability of default. On the other hand, SEDE has the highest negative effect on a leasing companies' probability of default, with a marginal effect of $-2.24 \%$.

Table 6

Results from Random Effects Binary Logit for the Unbalanced Panel of the leasing companies, the Panel Period 2005-2010

\begin{tabular}{|c|c|c|}
\hline Variables & Coefficient Estimates & Marginal Effects \\
\hline Constant & $\begin{array}{l}(15.278) \\
(4.97)^{* * *}\end{array}$ & \\
\hline UPPR & $\begin{array}{l}-0.2691 \\
(-2.96)^{* * *}\end{array}$ & -0.26904 \\
\hline ТPCO & $\begin{array}{l}0.8738 \\
(1.75)^{*}\end{array}$ & 0.87391 \\
\hline SEDE & $\begin{array}{l}-2.1018 \\
(-3.34)^{* * *}\end{array}$ & 2.10191 \\
\hline $\mathrm{CRCO}$ & $\begin{array}{r}-0.0103 \\
(-0.73)\end{array}$ & -0.01037 \\
\hline COGU & $\begin{array}{l}3.7996 \\
(5.06)^{* * *}\end{array}$ & 3.79986 \\
\hline $\begin{array}{l}\text { No.of Observations } \\
\text { Wald test }\end{array}$ & $\begin{array}{l}1554 \\
5584.41\end{array}$ & $\begin{array}{l}\text { P-value }(0.00) * * * \\
\text { Rhop (1) } 0.4632 * *\end{array}$ \\
\hline Log likelihood & -164.65 & \\
\hline Adjusted R-square & 0.21 & \\
\hline
\end{tabular}

\subsection{Forecasting powers of the model}

The compliance for the Logit model given with the McFadden $\mathrm{R}^{2}$ and the LR statistic for the correlated sample are calculated and demonstrated in Table 7. This shows that the LR is equal to 55.08 whereas the McFadden R2 for the Logit model is at $67 \%$, and statistically resulting at $1 \%$ which is within the corresponding asymptotic Chi-squared distribution. The explanatory power of the model was of two types for prediction error. A form I error occurs when the leasing companies are predicted to default but the result is non-default. A form II error occurs when the leasing companies are predicted not to default but the result is the default. As seen in Table 6, the predictive attainment for default and nondefault leasing companies and the two classes of errors, form I and form II is entailed. The cost of error form II is, though, more than the cost of error form I.

Table 7

The cost of form I errors and form II errors

\begin{tabular}{lll} 
& Type I error & Type II error \\
& Default & Non-default \\
\hline Original sample & 28 & 31 \\
Number of right predictions & 25 & 27 \\
Number of wrong predictions & 4 & 3 \\
Percentage of right predictions & 0.895 & 0.94 \\
Overall accuracy of Logit & 0.914963 & \\
\hline
\end{tabular}

The correct prediction for default leasing companies is about $90 \%$ when compared with $94 \%$ for a correct prediction of non-default leasing companies. In general, model precision is about $93.2 \%$, an acceptable value for the purpose of predicting default compared to other empirical models. The 
identifying indication for panel data models have a good overall fit - the probability ratio test statistics are significant at the $1.2 \%$ level of the random results binary Logit model. The probability ratio (LR) test declared at the foot of each table highlights the results which indicate the random accomplish model is noteworthy as a minimum at the $1 \%$ level of significance.

\section{Conclusion}

During the examination of this research the effect of up-front prepayments, time and period contracts, security deposits, the credit insurance contracts, collateral and guarantees and a variety of lease on default risk in the leasing industry have been found. A quantity of important descriptive statistics on the defaulted and non-defaulted leasing industrial and variables applied in the analysis have been provided. In order to guarantee that these findings are valid, several diagnostic tests were developed, such as, the heteroscedasticity test, correlation matrix, and the likelihood power model.

The result indicates that variables such as up-front prepayments, security deposits, credit insurance contracts and gross domestic product as measured by UPPR, SEDE, and CRCO procedures seem to be associated with corporate failure in the leasing industry. This result has proven significant in predicting the Likelihood of default, since, they have a negative impact on leasing companies' probability of default.

Variables such as the time and period contracts and interest rates as measured by TPCO, had a positive and significant effect on corporate failure in samples as it increased the likelihood of default. These results are normally consistent with the cash flow theory and economical failure theory. The results suggested that an increase in lease financing will decrease the bankruptcy probability. Decreasing time periods of leasing contracts will decrease the probability of credit risk. Third, increasing the amount of up-front prepayments of leasing contracts will decrease the probability of credit risk. Fourth, physical collaterals play a major role in reducing credit risk leasing.

\section{Acknowledgement}

The authors would like to thank the anonymous referees for constructive comments on earlier version of this paper.

\section{References}

Abdoh Tabrizi, H. (2009). Financial management Tehran: Shahid Beheshti.

Altman, E. I., Brady, B., Resti, A., \& Sironi, A. (2005). The link between default and recovery rates: Theory, empirical evidence, and implications. Journal of Business-Chicago, 78(6), 2203.

Altman, E. I. (1989). Measuring corporate bond mortality and performance. Journal of Finance, 44(4), 909-922.

Aven, T., \& Renn, O. (2009). On risk defined as an event where the outcome is uncertain. Journal of risk research, 12(1), 1-11.

Aven, T. (2010). On how to define, understand and describe risk. Reliability Engineering \& System Safety, 95(6), 623-631.

Beattie, V., Edwards, K., \& Goodacre, A. (1998). The impact of constructive operating lease capitalisation on key accounting ratios. Accounting and Business Research, 28(4), 233-254.

Bhattacharya, K. M. (2010). Risk management in Indian banks. Himalaya Publishing House.

Boobyer, C., \& Christopher, L. (2003). Leasing and Asset Financial. United Kingdom: Euromoney books.

Breusch, T.S., \& Pagan, A.R. (1979), A simple test for heteroscedasticity and random coefficient variation, Econometrica, 47, 1287-1294. 
Ching, W. K., Fung, E., Ng, M., Siu, T. K., \& Li, W. K. (2007). Interactive hidden Markov models and their applications. IMA Journal of Management Mathematics, 18(1), 85-97.

Deelen, L., Dupleich, M., Othieno, L., Wakelin, O., \& Berold, R. (2003). Leasing for Small and Micro Enterprises. ILO.

Dichev, I. D. (1998). Is the risk of bankruptcy a systematic risk?. Journal of Finance, 53(3), 11311147.

Elsas, R., \& Krahnen, J. P. (2000). Collateral, default risk, and relationship lending: an empirical study on financial contracting (No. 1999/13). CFS Working Paper.

Faulkender, M., \& Petersen, M. A. (2006). Does the source of capital affect capital structure?. Review of Financial Studies, 19(1), 45-79.

Feldstein, S. G., \& Fabozzi, F. J. (2011). The handbook of municipal bonds(Vol. 155). John Wiley \& Sons.

Grenadier, S. R. (1996). The strategic exercise of options: Development cascades and overbuilding in real estate markets. The Journal of Finance,51(5), 1653-1679.

Hildreth, W. B. (1993). State and local governments as borrowers: Strategic choices and the capital market. Public Administration Review, 41-49.

Kisgen, D. J. (2006). Credit ratings and capital structure. The Journal of Finance, 61(3), 1035-1072.

Krause, A. (2006). Risk Management. Bradford: GBR: Emerald Group Publishing Limited.

Lee, C. (2006). Advances in Quantitative Analysis of Finance and Accounting. River Edge, NJ, USA: World Scientific.

Lee, C. F. (2009). Advances in quantitative analysis of finance and accounting(Vol. 7). Airiti Press.

Philippe, J. (1996). Value at risk: the new benchmark for controlling market risk. Chicago: Irwin Professional.

Jurgita, B. (2011). An overview of the European leasing market in 2009. World Leasing Yearbook (edited by Adrian Hornbrook); A Euromoney Publication 2011, 46-55.

Madura, J. (2003). International financial management. South-Western.

McConnell, J. J., \& Schallheim, J. S. (1983). Valuation of asset leasing contracts. Journal of Financial Economics, 12(2), 237-261.

Miri, S. H. (2008). Leasing's role in the credit cycle Iran (Vol. 203). Tehran Institute for monetary and banking central bank of Islamic republic of Iran.

Nelson, C. H., \& Loehman, E. T. (1987). Further toward a theory of agricultural insurance. American Journal of Agricultural Economics, 69(3), 523-531.

Pozzolo, A. F. (2004). The role of guarantees in bank lending.

Porter, K. (2007). Bankrupt profits: The credit industry's business model for postbankruptcy lending. Iowa L. Rev., 93, 1369.

Rahmani, A. (2011). Leasing in Iran World leasing yearbook 2011, 1 (Eurmoney yearbook), 547.

Schallheim, J. S., Johnson, R. E., Lease, R. C., \& McConnell, J. J. (1987). The determinants of yields on financial leasing contracts. Journal of Financial Economics, 19(1), 45-67.

Schallheim, J. S., \& McCONNELL, J. O. H. N. (1985). A model for the determination of "fair" premiums on lease cancellation insurance policies. The Journal of Finance, 40(5), 1439-1457.

Schmit, M., \& Stuyck, J. (2002, September). Recovery rates in the leasing industry. In Working Paper presented at Leaseurope's Annual Working Meeting, Salzburg.

Schmit, M. (2004). Credit risk in the leasing industry. Journal of banking \& finance, 28(4), 811-833.

Shanmugam, K. R., \& Das, A. (2004). Efficiency of Indian commercial banks during the reform period. Applied Financial Economics, 14(9), 681-686.

Siu, T. K., Ching, W. K., Fung, E. S., \& Ng, M. K. (2005). Extracting information from spot interest rates and credit ratings using double higher-order hidden Markov models. Computational Economics, 26(3-4), 69-102.

Stewart, W. J. (1994). Introduction to the numerical solutions of Markov chains. Princeton Univ. Press.

Stickney, C., Weil, R., Schipper, K., \& Francis, J. (2009). Financial accounting: an introduction to concepts, methods and uses. Cengage Learning.

Tang, L. (2008). Credit risk. Master of Philosophy, Hong Kong. 
Tong, H. (1977). Discussion of a paper by AJ Lawrance and NT Kottegoda.Journal of Royal Statistical Society: Series A, 140, 34-35.

Woo, W. H., \& Siu, T. K. (2004). A dynamic binomial expansion technique for credit risk measurement: a Bayesian filtering approach. Applied Mathematical Finance, 11(2), 165-186.

Zeitun, R. (2009). Ownership structure, corporate performance and failure: Evidence from panel data of emerging market the case of Jordan. Corporate Ownership and Control, 6(4), 96.

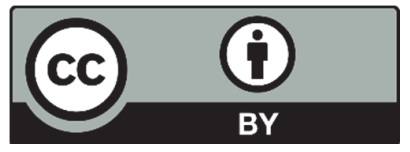

(C) 2016 by the authors; licensee Growing Science, Canada. This is an open access article distributed under the terms and conditions of the Creative Commons Attribution (CC-BY) license (http://creativecommons.org/licenses/by/4.0/). 